\title{
3
}

\section{Women as Fish: Rural Migration and Displacement in Vietnam}

\author{
Linh Khanh Nguyen
}

This chapter discusses the pattern of rural-to-rural migration to and from a rural fishing community called Hải Thành ${ }^{1}$ in northern Vietnam. ${ }^{2}$ I unpack this double migration pattern in order to illustrate the intimate relationship of mobility, social class and displacement. Hải Thành is famous in Vietnam as the community that has sent the largest percentage, nationwide, of its young women abroad in transnational marriages to foreign men in East Asia (transnational women). Hải Thành men are also well-known offshore fishermen who travel away 20 days per month and who, due to the transnational marriages of local women, have had to look for wives from other rural communities (translocal women). By comparing the gendered, racial and social elements of migration by translocal women with transnational women in this community, my chapter centres on how different kinds of movement become coded with specific kinds of class status and subjectivities. In order to accomplish this, I explore the diversity of rurality, within and between countries, which is often conflated in much scholarship as 'the rural'. I investigate how

\footnotetext{
1 Hải Thành is a pseudonym.

2 I gratefully acknowledge support for preparing this chapter from the ZEIT-Stiftung Ebelin und Gerd Bucerius Foundation, which has funded the author for two years. I also thank the 2014 ANU Vietnam Update organisers, Philip Taylor, and two anonymous reviewers for their comments on this chapter.
} 
migration from one rurality to another can be understood through the lens of social mobility. Ironically, this practice also engenders the social displacement of translocal women. This unwelcome ramification causes us to question the uncritical celebration of mobility and complicates the assumed linear, simplistic relationship between migration and social mobility. The case of translocal women in Hải Thành also illustrates that movement and non-movement are connected and mutually defining rather than dichotomised. Together, they create ongoing dynamics that characterise the lives of women in Hải Thành.

This chapter is based on 17 months of research in Hải Thành, from 2011 to 2014, including an 11-month period of intensive fieldwork from 2013 to 2014. During this time, I socialised with and interviewed local men, transnational women, and translocal women and their in-law families. I lived with two local families for more than a year, frequented Hải Thành people's homes and boats, ran errands with them, and attended local weddings and religious ceremonies. I took Korean classes with Hải Thành women and taught English classes for Hải Thành children. I also participated in the night life of Hải Thành, spending time in cafes and shops where young people hung out. These relationships and activities provided me with insights into the intimate and social life in Hải Thành, allowing me to understand their desires, values, prides, and struggles and disappointments as their lives are transformed by migratory forces, both internally and internationally.

\section{Hải Thành in Motion: The Fishermen and the Women}

Located near the Gulf of Tonkin, Hải Thành is a small rural fishing commune (xã) belonging to the Thuỷ Nguyên District (huyện) of Hải Phòng City in northern Vietnam with a population of around 12,000 people. Despite its small population and rural location, Hải Thành residents have a long history of movement and transnational migration. For example, Hải Thành men have been fishermen for generations and embark on monthly trips of 20 days to fish squid near Bạch Long Vĩ Island in the middle of the Tonkin Gulf (110 kilometres from home). Because the technique for fishing uses light attraction, Hải Thành 
fishermen are usually home every month from the 10th to the 20th day of the lunar calendar, for during this time the moon is bright, making prey harder to catch. Their monthly movement between the island and home is both circular and routinised.

The lucrative fishing industry of Hải Thành enables both the fishermen and the community to thrive. The majority of Hải Thành fishermen are boat owners who often hire workers from provinces in the centre of Vietnam to work on their boats because local labour cannot meet the demand of the growing fishing industry. Each boat worker gets paid 5 to 7 million VND (\$250-350 USD) per trip, which is relatively high according to local living standards. The rest of the profit or loss goes to the boat owners, who can earn more than 100 million VND $(\$ 5,000$ USD) on a good trip, but lose millions when hit by storms.

Although squid fishing is generally very profitable, it is certainly a laborious, treacherous and difficult job. Fishermen often talk about the long hours of work ( 12 hours or more per day) and how dangerous the job is, especially when the weather is rough (storms, cyclones, rain, high tides, etc.). The danger and hardship of the job, however, do not concern Hải Thành fishermen as much as the competition they face from Chinese fishermen. In December 2000, Vietnam and China signed an agreement concerning the delimitation of the continental shelf boundary in the Gulf of Tonkin in which Vietnam will occupy 53.23 per cent and China 46.77 per cent of the Gulf area. The two governments also established a joint fishing area between the two countries (BBC Vietnamese 2009; Uỷ Ban Biên Giới Quốc Gia 2000). While it is a joint fishing area, in reality only Chinese boats will fish in the area because Vietnamese boats cannot compete with them. According to Hải Thành fishermen, Chinese boats are at least five times bigger and 10 times more expensive, and their lights are so bright that they attract all the squid to their boats. It is only during 10 weeks in the summer (from April to June) when the Chinese government orders a yearly fishing ban (in an effort to rehabilitate marine resources) that Vietnamese boats will fish in the joint area. These two months are usually the most profitable of the year for the fishermen of Hải Thành.

While local men have been moving to the sea for generations, local women have been migrating to East Asia for marriages in the last decade. I refer to this group of women in my research as transnational women. In Vietnam, marriages between young rural Vietnamese 
women and Taiwanese and South Korean men are quite common. Socioeconomic changes in Taiwan and South Korea - such as changing gender expectations, outmigration of rural women, and the preferences for sons that result in more males than females have made it difficult for rural Korean and Taiwanese men to find spouses and caused them to look to Southeast Asia and China for prospective spouses. Statistics show that Vietnamese women are the second-largest group of transnationals, after Chinese women, to marry Taiwanese and South Korean men. From 1995 to 2010, around 300,000 Vietnamese women married East Asian men (Bélanger et al. 2010). Hải Thành is the rural commune that has the highest number of transnational women nationwide, estimated to be around 2,500 (Duong 2013). In a community of only 12,000 people, 2,500 women is a significantly high proportion. Transnational marriages between local women and East Asian men started in Hải Thành in the early 2000s with only 12 marriages. Since 2005, the number of transnational marriages has escalated annually, peaking in 2008, when 600 local women migrated to Taiwan and South Korea, according to Ms Ngọt, the chairwoman of the local Women's Union. The statistics from the Hải Thành Youth Union in 2013 show that the number of Hải Thành single women over the (legally marriageable) age of 18 who remain in the community is fewer than 20 (Duong 2013). In fact, the number of transnational marriages is so large that, since September 2012, the city of Hải Phòng has banned transnational marriages in several communes, including Hải Thành, after facing increasing complaints that local men could not find prospective wives. This ban, however, has not succeeded in limiting transnational marriages in Hải Thành as Hải Thành people just pay to have their residential status (hộ khẩu) transferred to different provinces on paper without actually moving. After the marriages are finalised and migration completed, they transfer their residence back again.

The popularity and feasibility of transnational marriages in Vietnam relies in no small part on the family networks and the private matchmaking agencies that facilitate transnational encounters and subsequent marriages. Vietnamese women who have successfully migrated through marriage can act as a go-between to find a husband for their sister or cousin. As such, transnational marriages through family networks can offer greater security and trustworthiness than marriages arranged through a matchmaker agency. The matchmaking 
agencies, however, are able to bring many Korean and Taiwanese men to Vietnam, allowing more choice to women and lessening the waiting time for suitable potential matches. They are, consequently, more popular than family networks in orchestrating transnational marriages. Often, the men have to bear most of the cost for transnational marriages. As Wang and Chang (2002) explained, for example, when a Taiwanese man wants to seek a Vietnamese wife, he must pay a fee of between \$7,000-10,000 USD. He then visits Vietnam where he is shown and introduced to a number of potential women at local hotels. All potential brides are brought together in a room and he moves from one woman to another, asking through a translator a few questions to whomever he finds attractive. He then selects a bride (this process usually takes less than an hour), a wedding is arranged soon after, and when the paperwork is done the bride migrates to Taiwan. To ensure a smooth process, the matchmaking industry includes sub-agents in both Taiwan/Korea and Vietnam who handle recruitment and paperwork. Information gained through my fieldwork indicates that transnational marriages between Vietnamese women and East Asian men cost around \$10,000 USD.

The popularity of transnational marriages in Hải Thành has also dramatically changed the nature of the marital transaction. Since the majority of transnational marriages happen in southern Vietnam, until the mid-2000s few Taiwanese/South Korean men looked for wives in the North, where Hải Thành is located. As the supply of willing wivesto-be surpassed the demand, Hải Thành families paid large sums of money ( $\$ 1,000-3,000$ USD) to matchmaker agencies to make sure that their daughters were introduced to Taiwanese/South Korean men and that the required paperwork was completed. It is a common saying in Hải Thành that local women bought their husbands. But the situation has now changed: since 2007, the number of transnational marriages in the South is declining, while it is gaining momentum in the North, especially in the city of Hải Phòng (Trung Kien 2013). The supply of Taiwanese/South Korean men has exceeded local demand and local women no longer have to pay money to matchmakers and have significantly more choice in deciding which men they want to marry. This situation applies to transnational marriages arranged by both agencies and family members. 
Since Hải Thành women opt to marry foreigners, Hải Thành men have no choice but to marry women from other places, usually remote places far from the community. Some local men who do not want to be fishermen have gone to big cities (such as Hồ Chí Minh city, Đồng Nai, or Hải Phòng city) to work in factories and have met their wives there. The division between the rural and the urban in Vietnam is clearly manifest in the fact that almost all of these women who marry Hải Thành men in big cities are themselves from rural places, having migrated to the cities for work. Once Hải Thành men get married and have children, most of them decide to return to Hải Thành, because the fishing industry there pays more, and because they have an extended family to care for and who will also help look after their own children. For the majority of Hải Thành men who are fishermen, their profession cripples their ability to find potential spouses. The long monthly trips away from home hinder their capability to court nonlocal women and maintain relationships. Many of them also have to resort to matchmakers. Ironically, their translocal marriages become very similar to the transnational marriages that they often criticise: there is often a matchmaker (an acquaintance of both sides), the bride and the groom meet briefly, and if they like each other a wedding will be held soon after. These women are often from rural areas poorer than Hải Thành and some are ethnic minorities (Thái, Nùng, Tày, and Hmong). The community at large and the women themselves consider translocal marriages as 'marrying up' for the women. Hải Thành, while still a rural place, is significantly wealthier than other rural localities thanks to foreign remittances and the profitable fishing industry. One can argue that, like transnational marriage, money also plays a role in translocal marriage. Additionally, once they get married, both the local and foreign husbands want their wives to stay home out of fear that they may become runaway wives. ${ }^{3}$

3 I personally only knew of two cases of runaway transnational and translocal women, but heard people say they knew of several women abandoning their husbands. When probed more closely, many of these stories were also second-hand. I suspect that the 'runaway bride' exists more as a cautionary tale than a common reality. 


\section{Women as Fish: Marriages in and out of Hải Thành}

While Hải Thành is a rural place, its highly mobile population has impressively changed the face of this once poor community. Local people always proudly say that their lives are equal to those in the cities. They constantly reminded me of that fact by pointing out that their incomes rival those of urbanites and by showing that they have nhà tầng (houses of multiple floors), xe xịn (expensive scooters), quán đêm (a night life) and so on. Hải Thành has received support from the city of Hải Phòng to widen its local port, to build new roads connecting it directly to the centre of the city, and to turn half of its farming land into housing projects by 2025 . But the most noticeable change created by the sudden wealth in Hải Thành is the lifestyle of young local people. Hải Thành people are famous for frequenting bars and restaurants, gambling, using drugs, dressing inappropriately and having carefree sexual relationships before marriage. The urbanites, of course, look down on Hải Thành people, taking these behaviours as proof that these rural yet financially able people lack cultural capital, are uncouth and insatiable. Urbanites in Hải Phòng often use the expression 'ăn chơi như người Thuỷ Nguyên' (dress and party like the Thuỷ Nguyên people) to mock the uncultured status of the rural people of this district in general, and of Hải Thành in particular.

The changes in the lifestyles of the young people are often used to explain the pattern of out- and in-migration in Hải Thành. Young Hải Thành women choose to marry Taiwanese and Korean men because they do not want to marry badly spoiled local men who supposedly waste money on drugs, alcohol, and gambling. Local men want to marry women from other rural localities because these women are not spoiled like Hải Thành women, who have a reputation for being lazy, extravagant, and promiscuous. Thus, a double rural-to-rural migration pattern is created due to marriages: translocal women move from rural places in Vietnam to Hải Thành, and transnational women move 
from Hải Thành to rural places in Korea and Taiwan. ${ }^{4}$ The internal rural-to-rural migration occurs to compensate for the transnational rural-to-rural migration.

While marriage is the driving force of the double rural-to-rural migration, to local people, especially fishermen, transnational and translocal women are viewed very differently. They are both described as fish, but while one can be caught, the other is elusive. The local way of fishing is to burn light bulbs at maximum capacity to attract squid and fish. After a while, the fish and squid become blinded by the lights, and that is when the fishermen pull the net up to catch them. Many fishermen told me that they use the same method to court translocal women: the fishermen show off their wealth and generosity while meeting the women, waiting for the 'blinded' moment to woo them into marriage. Of course, sometimes that tactic scares off women, but the majority of women in my research indicated that the financial difference between Hải Thành and their own community acts as an important factor in their marriage and migration.

Transnational women, on the other hand, are the good fish that get away. Similar to the way that Hải Thành fishermen complain that they cannot compete with Chinese fishermen over fishing, they also cannot compete with Korean and Taiwan men over local women. Moreover, the women, like the fish, have the ability to cross national borders while the (fisher)men are stuck within the border. The fish that gets away, as always, is seen as better. The fish that the Chinese fishermen catch are believed to be bigger, and the transnational women that the Korean and Taiwanese men marry are said to be better than translocal women.

The fish metaphor is very apt in showing that although very similar, translocal women are often judged to be inferior to transnational women. In the remainder of this chapter, I discuss how this comparison illustrates the intimate relationship of social class, migration and displacement.

4 Some transnational women reside in urban areas abroad and are considered luckier than those in rural areas. Urban residency is an increasingly important criterion for Hải Thành women when choosing their potential husbands. 


\section{The Rural as Destination: The Politics of Rural Migration}

Mobility scholars have recently noted the conceptual and cultural shift in the refashioning of identity in which movement becomes the basis of new identity formation (Urry 2000). There is an understanding that 'not only one can be at home in movement, but that movement can be one's very own home' (Rapport and Dawson 1998:27). As such, Urry (2000) spoke of a mobile identity, Beck (2006) of a cosmopolitan identity, and Clifford (1997) of an uprooted identity. Moving away from the literature on migration and diaspora that views movement as a form of dislocation and displacement from home, Chu (2010) argues that to move is to belong in a desirable world where mobility is often considered a force of social reproduction.

However, not all movement is the same, and where one moves matters. Some directions of migration - such as rural to urban, and domestic to international - are deemed attractive and beneficial, especially in postcolonial countries, for they are often associated with increases in economic and social status and cultural-cosmopolitan values (Salazar and Smart 2012). ${ }^{5}$ The consequences of these biases are twofold: ruralto-rural migration is often unnoticed, resulting in diverse ruralities becoming homogenous, and people who move from one rural locality to another, especially internally, are often excluded from the social and mobility capital associated with more desirable rural-to-urban or international migration.

Rural-to-rural migration is often ignored in mobility studies. Scholars tend to focus on rural-to-urban migration, both internally and internationally. Vertovec (2011) claims that the city is the foremost setting for the anthropology of migration because of its everyday multiculturalism and its large scale (see also Caglar 2010; Levitt and Jaworsky 2007; Brettell 2003; Bommes and Radtke 1996). As such, most recent research on migration and movement is based in big cities such as New York, Miami, Barcelona, Frankfurt, Manchester, London, and Beijing (Glick-Schiller and Caglar 2011; Foner 2010; Però 2007;

5 There is not always a preference for international migration over internal migration. Kalir's research shows that for small business entrepreneurs in booming China, moving abroad as construction workers actually means 'moving down' with respect to one's social mobility (Kalir 2013). 
Stepick et al. 2003; Zhang 2002). This lack of attention to the rural as a migration destination fails to account for the significance of rural localities as accessible, desirable and transformative migration destinations for many rural people. ${ }^{6}$ It also creates the biased assumption that only cities, and not rural places, are diverse, resulting in an unbalanced interpretation of migration.

It is the diversity of ruralities as well as the hierarchies among them that open up economic opportunities and contribute to the transnational and translocal marriages in Hải Thành. Most of the fishermen's wives are from relatively poor rural areas, ranging from the northern mountainous provinces (Bắc Giang, Bắc Kạn, Cao Bằng, Hà Giang, Lang Sơn) to the provinces of the mid-north coast (Thanh Hoá, Nghệ An) and Central Highlands (Buôn Mê Thuột). This is how a woman in Hải Thành described the home place of her daughter-in-law in Thanh Hoá when she visited it:

The road was small and very dark; there were not many lights like we have here. The houses were sparse and surrounded by forest. I jokingly told the in-law family that if they fought and the wife left, the husband would not be able to find her because she could easily hide anywhere. Their house was as big as the house I built for my chickens. It still did not have the concrete exterior layer and you could see the bricks in the wall. And there was no bathroom. Oh, if they had a bathroom like ours, it would have cost them a couple of hundred million.

The fact that their hometowns are poorer than Hải Thành is openly admitted by the translocal women themselves. They remark on the lack of jobs for young people and on the insufficient income from farming that creates hardship and distress for rural people. One translocal woman from Ninh Bình acknowledged:

My hometown is very poor and the majority of people are farmers. Even though we toil away in the fields, we barely make anything. It is a little better now, but not much. When I was young, we were so poor that my two older siblings did not go to school but stayed home to help my parents. The whole family depended on a small plot of rice.

6 For studies of rural-to-rural migration in Vietnam, see Carruthers and Dang (2012), Winkels (2012), Taylor (2007) and Hardy (2003). 
We also raised goats on the mountain, about 10 . We only sold one or two of them when we were in dire need, not daring to sell more in case we needed money later.

The poverty of rural Vietnam and the insufficiency of farming have pushed most rural youths looking for jobs to the cities. Hải Thành, however, is different. Most translocal women recognise that, compared to their hometowns, it is easier to make a living in Hải Thành. Although the amount of land for farming in Hải Thành is so small that most families do not sell their rice or vegetables; the women have access to other job options. Near the commune, within the rural district of Thuy Nguyên, are three textile and shoe factories where women can find work. Within the commune, jobs such as mending and fixing fishing nets and traps become available whenever the fishermen are home. Women can also go to Cát Bà Island to raise farmed fish and clams, or trade and sell seafood. However, these kinds of jobs provided by the fishing industry are often limited to local people who grew up in Hải Thành and know the ins and outs of fishing. Some translocal women have set up street-side shops to sell food and drink because Hải Thành people, unlike many other rural folk, have money to spend. Little profit is generated by these ventures, and most translocal women, even if they work, are still dependent on the income of their husband and parents-in-law. What differentiates women in Hải Thành from those in other rural areas of Vietnam is that many women in Hải Thành do not need to work to sustain their families.

Not only are there differences between ruralities in Vietnam, but also between those in Vietnam and South Korea. Although Hải Thành is considered better than many other rural places in Vietnam, it trails behind in comparison to rural areas in Korea. Rural Korea is described in local discourses as cleaner, more beautiful, more sufficient, and more modern. One Hải Thành woman, after visiting her daughter in Changwon, Korea, said:

They have a huge amount of land but they are able to work on all of it because they have machines. That is why they can live comfortably as farmers. Unlike us here, we always struggle with not making enough. There are plenty of jobs even for older people like me. And everything is so clean, no dust. Even in the summer, the sun is not unbearable and in the winter, you work inside the greenhouses; you don't freeze like you do in Vietnam. You know, my complexion was so much lighter after a year there and there was no dirt stuck in my fingernails even after work. It is just so much better. 
These economic differences, among other factors, motivate translocal and transnational marriages and migration, and make many women willing to marry outside of and far from their hometowns. These differences draw people to Hải Thành and rural Korea, turning them into rural places of great diversity. The literature on migration often fails to account for the differences among ruralities as they are conflated into 'the rural', and in so doing, little attention is paid to the rural-to-rural migration that is motivated by economic mobility. In my interviews and conversations with local women (before they marry transnationally) and translocal women, they express the hope that marriage will end their struggle to make ends meet and will help them achieve better lives for their children. Unfortunately, although economics are no longer much of a concern for both groups, translocal women do not necessarily reap the sorts of benefits of social mobility accorded to transnational women.

\section{Connection, Hierarchy and the Politics of Race, Class and Gender in Migration}

King and Skeldon (2010) have shown that a division remains in migration studies between internal and international migration, which form two almost entirely separate literatures with different conceptual, theoretical, and methodological standpoints that rarely talk to each other (see also Kalir 2013). Since the emergence of the 'migrationdevelopment nexus' in the 1990s, both scholars and policymakers have tended to focus almost exclusively on the relationship between development and international migration, overlooking the fact that, in most developing countries, internal migration is equally important (King and Skeldon 2010). This overemphasis on international over internal migration also stems from the intellectual bias that views 'nation' as the appropriate and significant unit of analysis (Wilding 2007; Hage 2005). The problem with the separation of internal and international migration is that it ignores many similarities in the migration processes between the two and provides only partial insights into the complex livelihoods of migrants and their communities (Glick-Schiller and Salazar 2013; Cohen 2011; King and Skeldon 2010). 
In Hải Thành, both internal and international migration are crucial to sustaining the community in terms of economy, lifestyle, and population. Their interconnection is clearly seen in the relationship between translocal women and transnational women in Hải Thành: the in-migration of translocal women compensates for the out-migration of transnational women. More importantly, the identity and status of one group is defined against those of the other group.

While transnational women and translocal women are similar in many aspects (they both, supposedly, marry up and both migrate from one rural place to another rural place), most people in Hải Thành, including the women themselves, insist that there are no similarities between the two groups. The differences cited are numerous. First and foremost is the amount of money that transnational and translocal women respectively remit to their parents. The remittances from transnational women can reach up to $\$ 4,000$ USD per year and can enable their parents to build new two-storey houses within three to five years, a major source of pride and social status in Hải Thành. After the houses are built, the remittances from transnational women are used to cover the living expenses of the parents and are put in the bank for investment. As a result, many parents of transnational women stop working and stay at home. They become a group of 'walking people': early morning or late afternoon, they (especially women) take a walk around the neighbourhood for daily physical exercise. Some even show off their comfortable lives by wearing 'modern' clothes and gold jewellery on their rounds. Local people told me that only 'walking people' have time to walk because they have transnational daughters; others are busy working. Wealth, in this community, is expressed through the body and having leisure time. More interestingly, even though both the fishermen and the walking people move in a circular manner (the former between home and Bạch Long Vĩ Island, the latter around the neighbourhood), fishermen have no choice but to move because their living depends on fishing. Urry wrote that 'unforced "movement" is power ... for individuals and groups a major source of advantage' (Urry 2007:51, emphasis added). Walking parents, by choosing to walk around the neighbourhood, show off their wealth and social status thanks to their daughters living abroad. Translocal women, on the other hand, mostly only give money to their parents at New Year, and the sum is small in comparison, ranging from \$50-100 USD. That sum is not sufficient to help their parents build houses or quit working to take a walk every day. 
Translocal women are also considered to be not as talented as transnational or local women. One Hải Thành resident summarised the commonly heard arguments:

If they [translocal women] were talented [giỏi giang], they would not be staying at home all the time. Moreover, if they were so talented, why would they have to marry so far away from home? They would have been taken by local men already.

Both of these lines of reasoning are problematic, because they fail to acknowledge in-marrying women's understandable lack of familiarity with the fishing industry, as well as how common translocal marriages have become throughout rural Vietnam. As agriculture has become a sure way to poverty (Taylor 2004), many young Vietnamese have migrated from rural to urban areas looking for jobs. This is where they meet their future spouses who, most likely, are from different hometowns. Therefore, the phenomenon of translocal marriages in Hải Thành is not uncommon, although I believe it is exacerbated by this locality's atypically high number of transnational marriages. As opposed to the non-talented translocal women, transnational (and local) women are considered more accomplished, according to Hải Thành residents, because they can go anywhere (to the islands or foreign countries) and still manage to make a good living, sending money home for their parents and the community at large. ${ }^{7}$ The difference in economic capacity translates into other status differences between the two groups. One of the translocal women from Nghệ An, Hoa, who married a local fisherman seven years ago, explained to me:

Woman: They have money so they are, of course, different from me. They are foreigners now and that is so different from us. They have money to show off; I don't have money so how can I compare with them, like how dare I walk side by side with them. There are times when I talk to them and they don't even bother to answer. They only talk to people with money. Even when they talk to me, it is just some superficial and quick stuff. They go abroad so they are high and rich [giàu sang] while I am low and poor [thấp hèn].

LKN: How do they show their differences?

7 See Thai (2014) for a study on why low-wage Vietnamese immigrants send home a large portion of their incomes and spend extravagantly on relatives during return trips. 
Woman: By how they walk. The way they walk is so different. I don't have money so I walk like a normal person. They have money so they sashay like a supermodel. And they talk with airs and graces, lengthening the tone. Instead of saying 'I do this', they will say 'Iiiiiiiii do thiiiiiiiiiis'. You know, instead of just saying it right out, they have to say it like it is so special. Then they will add foreign words to their conversations and talk with a foreign accent, like a Westerner speaking Vietnamese. How strange, you know, because they are Vietnamese. Even their gestures are for putting on airs. For example, if they need to get something from their pocket, their thumb and index fingers will touch each other while the other three fingers are extended up. Of course, not all of them are like that.

LKN: Are there any other ways you can tell that they are transnationals?

Woman: The most obvious signs are their clothes and their complexions. Their complexions are beautiful, lighter and pinkish because they do not have to work over there. And because they have gone abroad, they know how to dress really nicely. Their clothes look very different from the clothes you can buy here. We, on the other hand, just dress simply.

This dialogue shows how transnational women are perceived as having a high social status, and consolidate their status by acting like they are more refined and imbuing themselves with the qualities of foreigners. The translocal woman's choice of words suggests that even though transnational women are evaluated as fake and pretentious, owing to how they walk and talk, they are still envied because they embody certain qualities associated with life abroad (cuộc sống Việt Kiều) that are out of reach for translocal women: fashionable clothes, fairer complexion, and exemption from the dirty, hard agricultural work that makes women less attractive.

The attractiveness of the foreign in a postcolonial society such as Vietnam is often shaped not only by money but also by arrangements of power such as colonialism, capitalism, and modernity. As Gupta (1998) and Chakrabarty (2000) argue, the former colonial power and capitalism become the standard against which those living in the former colony are measured, and always fail. My conversations with Hải Thành people reveal that the West stands for everything that is desirable and in opposition to what dissatisfies them in Vietnam: capitalist (vs communist economy), industrial (vs agricultural), cosmopolitan (vs rural), democratic (vs totalitarian), offering opportunities to 
make money and travel (vs the lack thereof), and clean (vs polluted). Even though South Korea and Taiwan do not belong to the West, they are accorded all of the Western characteristics listed above. Korean and Taiwanese people are not white, but their skin colour is still much lighter than that of a Vietnamese person. South Korea and Taiwan, the so-called Asian dragons, have therefore become the Asian role models for the Vietnamese in their quest to catch up with the West. It is understandable then that the Vietnamese transnational women who have changed themselves into Koreans and Taiwanese are viewed as more modern, classy and wealthy than the simple rural Vietnamese in Hải Thành. The differences are shown in not only how translocal women view transnational women but also the other way around. A transnational woman remarked of her sister-in-law:

I cannot clearly say why but the way she dresses just makes her look dirty [bẩn]. It's not that the clothes are unclean but she looks kind of dirty. She also does not have her nails done so her hands do not look nice. And she walks loudly; I can recognise her by the noise she makes. When we eat, I have the feeling that she just eats a lot. I don't know. I just do not talk to her much.

The body and lifestyle are once again used to delineate hierarchical status and class difference between translocal and transnational women. Besides economic differences, I believe that translocal women do not earn much cultural capital after moving because of the politics of migration, which favour the urban and the cosmopolitan. In the case of translocal women in Hải Thành, their marriage migration to a rural, internal place does not relieve them of the status of 'rural women'. Despite having mobile and uprooted identities, they are still regarded in Hải Thành as rural and backward, and are devalued by their unpleasant behaviours as well as their unappealing, unhygienic bodies. We see repeatedly the importance of dressing, maintaining beautiful hands, and hygiene (dirty vs clean, the white/black binary transformed into fairer/darker skin) as markers of social class among women. In other words, the body is a site where social differences are articulated.

As Jones (2001) notes, clothes are important elements of selfpresentation and significant markers of class boundaries. In Hải Thành, clothes indicate conformity with different ideals of femininity. To dress 'like Koreans' or dressing 'simply' are modes of self-presentation that visibly separate transnational and translocal 
women, and signal different class affiliations (cosmopolitan vs rural). Similarly, Jiang (2014) argues that hand fetish and hygiene is the new class indicator, distinguishing the higher class from the 'dirty' working class. In Industrial times, the hands were associated with manual labour, a lower form of labour compared to the more advanced mechanical labour. As such, a measure of modernity is the extent to which the hands are freed from labour. Beautiful hands have, arguably, become the representation of civilisation and modernity (Jiang 2014). This global obsession with manicure is more than simply a question of women's unattainable beauty standards and oppression, but is also a tool for women to negotiate their social statuses (Kang 2010). In her study in New York, Kang concludes that the reasons women have their nails done vary from having higher self-esteem, attractiveness to partners, stress relief, bonding with other women, career advancement, and increased mobility (Kang 2010). Depending on their social positions, defined by race, sexuality and social class, the meanings and rewards of manicures and beauty differ among women. For example, airbrushed nails, while considered to be beautiful by many African American women, stigmatise them as belonging to a lower social class. At the same time, by choosing a more 'boring' middle-class nail style (French manicures and pastel colours), a working-class woman can elevate her status to that of a professional. As Kang convincingly shows, nails 'grow out of $\ldots$ bodies but also out of social relations and circumstances in which these bodies are embedded' (Kang 2010:132).

Manicure, for women in Hải Thành, is a ticket to an exclusive club of women who have the money and time to pay attention to beauty and pampering. Translocal women, who undertake agricultural and fisheries related work, considered both dirty and hard, and who do not have disposable incomes, cannot join this club. Few, if any translocal women in Hải Thành known to me have their nails done, yet all know where the nail salons are and the exact cost of each specific style. Their knowledge of manicures comes from listening to transnational and local women talking about manicures. Transnational women in Hải Thành, by having manicures done and criticising translocal women for not doing so, are essentially claiming their bodies as both special and normative, consequently reinforcing their class privilege. At the same time, translocal women's failure to keep their hands 'clean' and nice is understood as a personal defect rather than as a re/construction of marginality and disadvantage. Therefore, in the same way that the non-white body is the marked other against which the ideal woman is 
defined (Collins 2005; Bettie 2003), the rural woman's body becomes a spectre against which a cosmopolitan, urban ideal is defined. In other words, transnational women's beauty and privilege has no meaning without the failure of the rural translocal women to measure up against. The women's hands express both a privileged distance from hard labour and bind the articulation of class with the articulation of gender.

What is most surprising to me, however, is how the class hierarchy is mapped onto ethnic differences in Hải Thành. Often Hải Thành people told me that the in-marrying daughters-in-law of their neighbours are very rural (quê) because they are 'ethnic minority people' ('người dân tộc', commonly contracted in Hải Thành as 'tộc'). The term 'ethnic minority' in Vietnam has such a negative meaning that it easily turns into racial categorisation, loaded with connotations of primitiveness and even savagery. Such connotations can be seen in the remarks made by one Hải Thành man about his daughter-in-law, who is an ethnic Thái woman from Thanh Hoá:

She's very different from us here. Her true nature [bản chất $\ldots$... she argues all the time with her husband. If he says one sentence, she has to say another. If needed, she can physically fight her husband, unlike women here. Fight till the end! Before moving here, she lived in the mountains. From the road to her house on the top of the mountain, it takes more than an hour of walking. Their lifestyles are strange: they do not grow any food or raise any livestock. Instead, they just go into the woods and fetch whatever they can find for the day. Absolutely no long-term thinking. There is nothing to live on over there. It's exactly like how the TV portrays the ethnic life. I don't really understand her and I don't trust what she says yet. Because of her background, it is very hard for me to teach her.

The man implied that ethnic people are marginal, wild and primitive, both in their lifestyles and their personality. They are also dangerous and cannot be trusted, which makes them difficult to restrain and discipline. This representation is in line with the dominant discourses in Vietnam that fortify the binaries of majority-minority, modernancient, and civilised-barbarian (Michaud 2010).

Even though there are indeed minority ethnic women marrying local men, the number is small, and most translocal women who are assumed to be of ethnic minority background actually are not. When I questioned Hải Thành people about why they claimed these 
women to be ethnic minorities when they were not, they explained: 'We were just joking. It is because ethnic people are very honest, thus not very smart [ngố] even though they like money [tham tiền]. They also dress very rurally.' I witnessed how often the derived contraction 'ethnic' (tộc) is used in Hải Thành to talk about differences. When a grandmother jokingly told her five-year-old granddaughter, 'You must be ethnic $[t o \hat{c} c]$ because you dress so funny,' she cried, 'No, I am not ethnic. My mum is ethnic but I am not because my Dad is not.' Her mother, a translocal woman, is a Kinh woman, not a minority. In other words, the 'bad' and 'backward' qualities of translocal women are mapped onto 'ethnic' inferiority. The ethnic mapping of class indicates a permeating but normalised hierarchy between the Kinh and other minorities in Vietnam. It is so normalised that Hải Thành people go about branding people they deem different and inferior to themselves as 'ethnic'. Here we see the categories of ethnicity and social class collapsed into one, which is conflated with the figure of the rural woman.

In Hải Thành, ideologies of race and class have combined to shape an ideal femininity that draws new forms of inclusion and exclusion along the rural/urban, local/global and majority/minority divide. Modern Hải Thành women fashion their identity by conforming to a Western/ white ideal of beauty (fairer skin colour, being cosmopolitan, clean hands, nice clothes) and create their different other in the 'ethnic' rural women (dark skin colour, being remote, ugly hands, dirty clothes). As such, rural women are discriminated against because they are perceived to embody ethnic/racial inferiorities. ${ }^{8}$

The exclusion of rural women from modern Vietnamese society at large can be traced in the covers of books and magazines on women, in particular, how women can become modern, wonderful, and seductive. The female models on these covers are fairly similar in terms of styles and beauty (white stylish clothing, careful make-up, and accessories) (Figure 1). Take, for example, the book titled Phụ nữ Hiện đại Thế kỷ XXI (Modern women of the 21st Century) published by the Lao Động Press in 2011. The modern Vietnamese woman, shown on the cover, has her hair and nails done and wears jewellery and make-up. Her outfit

8 It should be noted that the politics of race, class and gender play out quite similarly for Vietnamese transnational women in Taiwan and South Korea. Vietnamese transnational women are also rejected in East Asia because they are rural women from a less economically developed country (Tsai 2011; Epstein 2008; Hsia 2007, 2008; Lee 2008; Sheu 2007; Wang 2007; Lee et al. 2006). 
is a modernised version of a suit and she seems to be standing in front of a multistorey office building. It is noteworthy that she has a fair complexion and is wearing white clothing, reinforcing the Western beauty standards. In other words, the modern Vietnamese woman is a chic 'white' urban businesswoman rather than a plain, 'dirty' farmer.

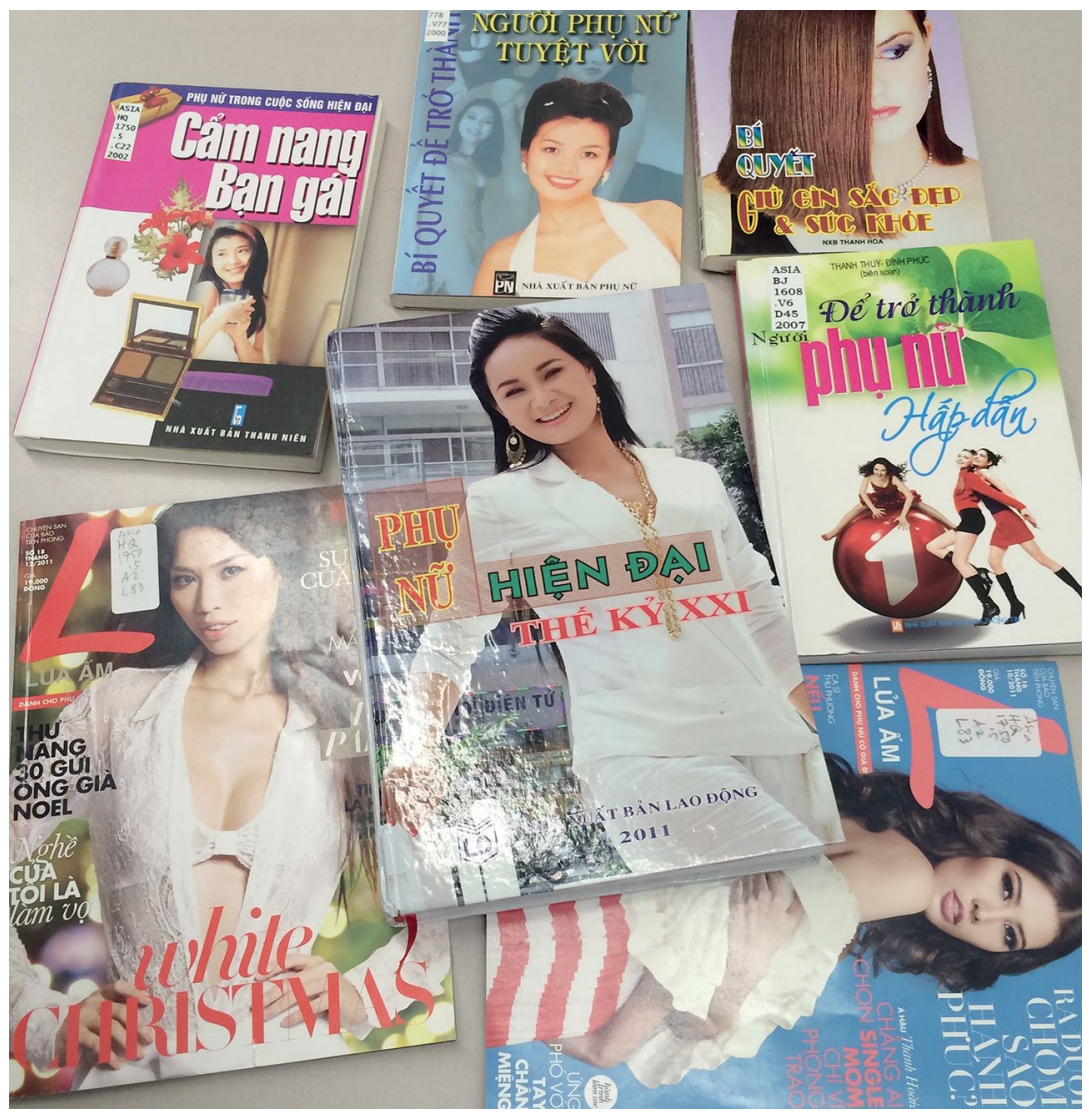

Figure 1: The cover of Modern Women of the 21st Century.

Photograph by the author.

These perceived racial differences, along with social and economic differences, consolidate the hierarchy between transnational women and translocal women. This hierarchy reflects important differences between international and internal migration, demonstrating that not all migrations are the same and that the destinations of migration (rural or urban, local or global) are significant in the socioeconomic values and evaluation of migration. While mobility in the global world is usually 
accorded positive value, the marginal status of translocal women in Hải Thành challenges the simplistic and assumed relationship between migration and social, financial and cosmopolitan climbing.

\section{Fish out of Water: Migration, Immobility and Displacement}

Apart from generating social mobility, physical mobility has also been celebrated for its association with freedom, liberation, and resistance. The romanticisation of mobility in the image of the nomad is evident through the works of Mackinders, Deleuze and Guattari, and Bachelard, all of which connect mobility with power; specifically, they perceive in the nomad the ability to evade power and link mobility with freedom and liberty (Adey 2009). However, the case of translocal women shows that they are not only considered inferior but are also controlled and marginalised in Hải Thành. The marginalisation of translocal women in Hải Thành is revealed, first, in their physical immobility and confinement in the home. Unlike those who move to the cities for jobs, translocal women who have migrated to Hải Thành for marriages often find themselves unemployed. The lack of paid work for rural women in Vietnam in general, and the fact that most translocal women are under-educated, make many of them stay-at-home housewives. They might do some seasonal farming if their families do not rent out their plots or hire people to do the work. However, the amount of land for cultivation available to each household in Hải Thành is so limited that agricultural work does not take much time. Moreover, translocal women often reside with their parents-in-law and are financially dependent because the parents-in-law control the family budget.

Because of their ambiguous position as outsiders who are also now insiders, they are not trusted by local people. ${ }^{9}$ Translocal women rarely visit their neighbours, as local people and their parents-in-law would view these visits as occasions for gossip. As I was told by local people:

9 For studies on the lack of trust and discrimination against migrants from other provinces and ethnicities in Vietnam, see Winkels (2012), McElwee (2008), and Hardy (2003). 
What else besides gossip will they talk about? They don't have jobs. They stay at home. They don't understand the politics and economics of the country or this community. What do they have to talk about besides gossiping?

In Vietnam, gossiping generally means speaking ill of your family and neighbours. In a small rural place such as Hải Thành, where everyone knows and is related to each other, the subject of gossip will spread like wildfire. Gossip is an unspoken taboo in Vietnamese face-saving culture (Hữu Ngọc 2004). Gossip is gendered, in the sense that men are said to talk about national and big ideas (đàn ông bàn việc nước và việc lớn) while women are considered to be only concerned with petty talk (phu nữ hay buôn dưa lê). ${ }^{10}$ The fear of gossip and its association with women explains why translocal women, when asked why they did not visit their neighbours, said they did not feel welcome. The fishermen, on the other hand, never said to me that they were not received warmly when visiting their neighbours or friends. It is as though men can talk outside of the confines of the home but translocal women cannot.

I witnessed this lack of trust in translocal women and the worry about gossip during my fieldwork. Most translocal women whispered when talking to me, for fear of their parents-in-law overhearing our conversations. Sometimes their parents-in-law would take over and answer my questions on their behalf. Even worse, many of my interviews and connections with translocal women were cut off after I happened to meet their parents-in-law in their houses. Then when I visited again, the parents-in-law would say to me that their daughter-in-law had gone elsewhere, or the translocal woman would text me and tell me not to contact her again. In some instances in which a woman had disclosed to me the details of her situation, I could speculate that, for example, the parents-in-law did not want me to know that they had lied to their daughter-in-law about having more money than they actually did, or that their son had been divorced by his first wife because he was a drunkard. In other cases, I had no grounds for speculation, as I was yet to know much about the woman's story. Given that I never faced a similar problem talking to other groups in Hải Thành, this abrupt disengagement reveals quite clearly the translocal women's status as outsiders who need to be controlled.

10 This belief is strongly linked to Confucian ideology that educated men are leaders both in terms of social morality and the formation of society (Luong 2010). 
Besides the dreaded gossip, parents-in-law and husbands also like to keep translocal women inside the home for fear of infidelity due to the absence of their husbands for 20 or more days every month. To make matters worse, local women look down on translocal women and do not socialise with them. The reasons are various: we don't know them, they dress in an ugly and dirty manner, they do not know how to have fun, they are not generous. As a result, translocal women end up being socially and physically isolated, and their social network consists of only their in-laws and their cousins if they have married local men. Local people often say that they do not see translocal women much and do not really know who they are. The irony is that while the local people, especially the parents-in-law, often boast about the 'good' lives of translocal women (they really do not have to work much besides a bit of farming; they only stay home and look after their children; compared to women in other rural places, their lives are 10 times better), translocal women often feel constrained and inferior. One of the translocal women told me how much she enjoys working in the textile sweatshop. Even though she is poorly paid and works very long hours, the workplace provides her with a much-needed social network:

I have friends there, you know. People who I can talk to during lunch, people who I can hang out with. We eat together and we take a nap together. Sure, the hours are long and I have to stand on my feet all day - they are sore often. Sometimes, especially in the winter, I come home so late that the whole house has gone to sleep. I still have to make dinner for myself and eat by myself; I feel quite lonely. ${ }^{11}$ But staying home is even lonelier.

The marginalisation of translocal women in Hải Thành is further demonstrated by their invisibility in local discourses. There is no term that describes translocal women as a group in Hải Thành. Hải Thành people use Kiều Đài Loan, Hàn Quốc (Taiwanese and Korean transnationals) to refer to transnational women, and gái Hải (Hải women), a shortened form of gái Hải Thành (Hải Thành women), to refer to local women. But translocal women are not assumed to belong to either of these groups. If they ever get talked about, it is usually as specific wives of specified fishermen, never as a group. Even though translocal women often distinguish themselves from local women,

11 Her husband is a fisherman, so he is not home most of the time. 
Hải Thành people do not compare local women to translocal women, but to women in other places. In other words, translocal women rarely appear in local discourse. This linguistic absence indicates that translocal women have no identity outside of being defined in relation to men (being local men's wives). It seems that for translocal women there is no public acknowledgement of their life histories, struggles or identity outside of marriage. They are defined by heterosexual and patriarchal language that designates them as subject to male authority.

The denial of a place for translocal women in local discourse has other political implications. As Foucault noted, discourses are 'practices that systematically form the objects of which they speak ... Discourses are not about objects; they do not identify objects, they constitute them and in the practice of doing so conceal their own intervention' (Foucault 1972:49). Discourse, in creating the subject through marking the boundaries of exclusion, leaves behind the silenced group who, because of linguistic absence, have no way of articulating their subjecthood. Translocal women, in a Lacanian understanding, are a signified (a reality) without a signifier (a place in language) and are therefore 'real' but outside of the discursive reality.

Being made invisible, indeed, is one painful form of oppression, as Butler illustrated:

Indeed, one can be interpellated, put in place, given a place through silence, through not being addressed, and this becomes painfully clear when we find ourselves preferring the occasion of being derogated to the one of not being addressed at all. (Butler 1997:27)

The invisibility of translocal women implies being ignored, devalued, rejected and not being heard. It also denies the independence and desirability of their identity, since they are neither attractive nor significant enough to even be identified. The displacement of translocal women is twofold: they are denied a linguistic place in the community of speakers, as well as a physical place in public spaces where they can participate in community life. They are, in short, refused a place of being and of having possibilities for human relationships. Their displacement is the problem of placelessness.

In many ways, translocal women are the fish that get caught from somewhere else and are out of water once in Hải Thành. The fact that they are young and relatively newly wedded matters much in how 
well they are integrated in the community. They have not been able to gain the trust and respect from their in-law families, neighbours, and people in the commune. They also have not made friends and social connections outside of their immediate families. Given how isolated translocal women are, I suspect that it will take them a very long time to feel accepted and comfortable in Hải Thành.

The question of belonging, writes Vijayasree, 'acquires an additional edge of urgency and poignancy in the case of female migrants, because, for them, the issue of self-definition can hardly be isolated from larger questions of gender' (Vijayasree 2000). Vijayasree talks about Indian writers in the West, but her comment also illuminates the predicament of translocal women in Hải Thành. Their migration is a re-entry into the northern Vietnamese patriarchal structure that excludes women as outsiders (ngoai tộc), by tracing descent through men, patrilocal residence, and an emphasis on male authority (Luong 2010). Their migration, instead of bringing freedom and social mobility, reinforces their female status as being displaced, invisible, and, ironically, immobile. Indeed, one does not need to migrate out of the country to be displaced; one can be displaced by being right at home and being a woman.

By focusing on the migration of translocal women and comparing this with the migration of transnational women, I join other mobility scholars in questioning the celebration of movement as a universal benefit (Glick-Schiller and Salazar 2013; Mai and King 2009; Partridge 2009; Ahmed 2004; Skeggs 2004; Tsing 2002; Tesfahuney 1998; Massey 1993). The displacement and confinement of translocal women in Hải Thành reveals that mobility can produce immobility, and that movement and non-movement are not fixed binaries. Instead, mobility and immobility are relative and interrelated. I have underlined that not all migrations are the same, and that the question of who moves where and under what conditions does matter. The focus in this study on diverse trajectories of migration sheds light on the hierarchy of mobilities that exists in Vietnam, and on the differentiations in status, personhood, and rurality that are implicated in these migrations. Only by paying attention to these complex dynamics of mobility, personhood, and place can we understand how marriage, migration, and social worth intermesh - like the often tattered and sometimes empty nets of the fishers of Hải Thành. 


\section{References}

Adey, Peter 2009, Mobility (Key Ideas in Geography), Routledge, London.

Ahmed, Sara 2004, The Cultural Politics of Emotion, Edinburgh University Press, Edinburgh.

BBC Vietnamese 2009, 'TQ tuần tra nghề cá ở Vịnh Bắc Bộ' ['China Performed Fishery Patrol in the Tonkin Gulf'], 31 May 2009, available at www.bbc.com/vietnamese/vietnam/2009/05/090531_ china_fishery_patrol.shtml, accessed 14 August 2013.

Beck, Ulrich 2006, The Cosmopolitan Vision, Polity, Cambridge.

Bélanger, Danièle, Hye-Kyung Lee and Hong-Zen Wang 2010, 'Ethnic Diversity and Statistics in East Asia: "Foreign Brides" Surveys in Taiwan and South Korea', Ethnic and Racial Studies, vol. 33, no. 6, pp. 1108-1130.

Bettie, Julie 2003, Women without Class: Girls, Race and Identity, University of California Press, Berkeley.

Bommes, Michael and Frank-Olaf Radtke 1996, 'Migration into Big Cities and Small Towns: An Uneven Process with Limited need for Multiculturalism', Innovation: The European Journal of Social Science Research, vol. 9, no. 1, pp. 75-86.

Brettell, Caroline B. 2003, 'Bringing the City Back In: Cities as Contexts for Immigrant Incorporation', in Nancy Foner (ed.), American Arrivals: Anthropology Engages the New Immigration, School of American Research Press, Santa Fe, pp. 163-196.

Butler, Judith 1997, Excitable Speech: A Politics of the Performative, Routledge, London.

Caglar, Ayse 2010, 'Rescaling Cities, Cultural Diversity and Transnationalism: Migrants of Mardin and Essen', in Steven Vertovec (ed.), Anthropology of Migration and Multiculturalism: New Directions, Routledge, London, pp. 113-138. 
Carling, Jørgen 2008, 'The Human Dynamics of Migrant Transnationalism', Ethnic and Racial Studies, vol. 31, no. 8, pp. 1452-1477.

Carruthers, Ashley and Trung Dinh Dang 2012, 'The Socio-spatial Constellation of a Central Vietnamese Village and its Emigrants', Journal of Vietnamese Studies, vol. 7, no. 4, pp. 122-153.

Chakrabarty, Dipesh 2000, Provincializing Europe: Postcolonial Thought and Historical Difference, Princeton University Press, Princeton.

Chu, Julie Y. 2010, Cosmologies of Credit: Transnational Mobility and the Politics of Destination in China, Duke University Press, Durham, NC.

Clifford, James 1997, Routes: Travel and Translation in the Late Twentieth Century, Harvard University Press, Cambridge, Mass.

Cohen, Jeffrey H. 2011, 'Migration, Remittances, and Household Strategies', Annual Review of Anthropology, vol. 40, pp. 103-114.

Collins, Patricia H. 2005, Black Sexual Politics: African Americans, Gender and the New Racism, Routledge, New York and London.

Duong, Yen 2013, 'Nơi đàn ông khó lấy vợ' ['The Village Where Men Have Difficulties Finding Wives'], 11 February 2013, Người Đưa Tin [News Delivery People], available at www.nguoiduatin.vn/ chuyen-bi-hai-o-noi-dan-ong-kho-lay-vo-a67774.html, accessed 6 November 2013.

Epstein, Stephen 2008, 'The Bride(s) from Hanoi: South Korean Popular Culture, Vietnam and "Asia" in the New Millennium', Citizenship Studies, vol. 12, no. 1, pp. 9-25.

Foner, Nancy 2010, 'How Exceptional is New York?: Migration and Multiculturalism in the Empire City', in Steven Vertovec (ed.), Anthropology of Migration and Multiculturalism: New Directions, Routledge, London, pp. 39-64.

Foucault, Michel 1972, The Archaeology of Knowledge, Tavistock, London.

Glick-Schiller, Nina and Ayse Caglar (eds) 2011, Locating Migration: Rescaling Cities and Migrants, Cornell University Press, Ithaca, NY. 
Glick-Schiller, Nina and Noel B. Salazar 2013, 'Regimes of Mobility across the Globe', Journal of Ethnic and Migration Studies, vol. 39, no. 2, pp. 183-200.

Gupta, Akhil 1998, Postcolonial Developments: Agriculture in the Making of Modern India, Duke University Press, Durham NC.

Hage, Ghassan 2005, 'A Not So Multi-sited Ethnography of a Not So Imagined Community', Anthropological Theory, vol. 5, no. 4, pp. 463-475.

Hardy, Andrew 2003, 'Migrants in Contemporary Vietnamese History: Marginal or Mainstream?', in Abu Talib Ahmad and Tan Liok Ee (eds), New Terrains in Southeast Asian History, Ohio University Press, Athens, Ohio, pp. 328-353.

Hsia, Hsiao-Chuan 2007, 'Imaged and Imagined Threat to the Nation: The Media Construction of the "Foreign Brides' Phenomenon" as Social Problems in Taiwan', Inter-Asia Cultural Studies, vol. 8, no. 1, pp. 55-85.

Hsia, Hsiao-Chuan 2008, 'Beyond Victimization: The Empowerment of "Foreign Brides" in Resisting Capitalist Globalization', China Journal of Social Work, vol. 1, no. 2, pp. 130-148.

Hữu Ngọc 2004, Wandering through Vietnamese Culture, Thtureii Publisher, Hanoi.

Jiang, Jing 2014, 'From Foot Fetish to Hand Fetish: Hygiene, Class, and the New Woman', Positions: East Asia Cultures Critique, vol. 22, no. 1, pp. 131-159.

Jones, Dorothy 2001, 'Defining Self and Others through Textile and Text', Women's Writing, vol. 8, no. 3, pp. 375-390.

Kalir, Barak 2013, 'Moving Subjects, Stagnant Paradigms: Can the "Mobilities Paradigm" Transcend Methodological Nationalism?', Journal of Ethnic and Migration Studies, vol. 39, no. 2, pp. 311-327.

Kang, Miliann 2010, The Managed Hand: Race, Gender, and the Body in Beauty Service Work, University of California Press, Berkeley. 
King, Russell and Ronald Skeldon 2010, "“Mind the Gap!": Integrating Approaches to Internal and International Migration', Journal of Ethnic and Migration Studies, vol. 36, no. 10, pp. 1619-1646.

Lee, Hye-Kyung 2008, 'International Marriage and the State in South Korea: Focusing on Governmental Policy', Citizenship Studies, vol. 12, no. 1, pp. 107-123.

Lee, Yean-Ju, Dong-Hoon Seol and Sung-Nam Cho 2006, 'International Marriages in South Korea: The Significance of Nationality and Ethnicity', Journal of Population Research, vol. 23, no. 2, pp. 165-182.

Levitt, Peggy and B. Nadya Jaworsky 2007, 'Transnational Migration Studies: Past Development and Future Trends', Annual Review of Sociology, vol. 33, pp. 129-156.

Luong, Hy Van 2010, Tradition, Revolution, and Market Economy in a North Vietnamese Village, 1925-2006, University of Hawaii Press, Honolulu.

Mai, Nicola and Russell King 2009, 'Love, Sexuality and Migration: Mapping the Issue(s)', Mobilities, vol. 4, no. 3, pp. 295-307.

Massey, Doreen 1993, 'Power-Geometry and a Progressive Sense of Place', in John Bird, Barry Curtis, Tim Putnam and Lisa Tickner (eds), Mapping the Futures: Local Cultures, Global Change, Routledge, New York, pp. 59-69.

McElwee, Pamela 2008, “'Blood Relatives" or Unfriendly Neighbors?: Vietnamese-Ethnic Minority Interactions in the Annamite Mountains', Journal of Vietnamese Studies, vol. 3, no. 3, pp. 81-116.

Michaud, Jean 2010, 'Editorial: Zomia and Beyond', Journal of Global History, vol. 5, no. 2, pp. 187-214.

Ong, Aihwa 1999, Flexible Citizenship: The Cultural Logics of Transnationality, Duke University Press, Durham, NC.

Partridge, Damani James 2009, 'Travel as an Analytic of Exclusion: Becoming Noncitizens, and the Politics of Mobility After the Berlin Wall', Identities: Global Studies in Culture and Power, vol. 16, no. 3, pp. 342-366. 
Però, Davide 2007, 'Migrants and the Politics of Governance: The Case of Barcelona', Social Anthropology, vol. 15, no. 3, pp. 271-286.

Rapport, Nigel and Andrew Dawson 1998, Migrants of Identity: Perceptions of Home in a World of Movement, Berg, New York.

Salazar, Noel B. and Alan Smart 2012, 'Anthropological Takes on (Im)mobility', Identities: Global Studies in Culture and Power, vol. 18, no. 6, pp. i-ix.

Sheu, Yea-huey 2007, 'Full Responsibility with Partial Citizenship: Immigrant Wives in Taiwan', Social Policy and Administration, vol. 41, no. 2, pp. 179-196.

Skeggs, Beverley 2004, Class, Self, Culture, Transformations, Routledge, London.

Stepick, Alex, Guillermo Grenier, Max Castro and Marvin Dunn (eds) 2003, This Land is Our Land: Immigrants and Power in Miami, University of California Press, Berkeley, CA.

Taylor, Philip (ed.) 2004, Social Inequality in Vietnam and the Challenges to Reform, Institute ISEAS Publications, Singapore.

Taylor, Philip 2007, 'Poor Policies, Wealthy Peasants: Alternative Trajectories of Rural Development in Vietnam', Journal of Vietnamese Studies, vol. 2, no. 2, pp. 3-56.

Tesfahuney, Mekonnen 1998, 'Mobility, Racism and Geopolitics', Political Geography, vol. 17, no. 5, pp. 499-515.

Thai, Hung Cam 2014, Insufficient Funds: The Culture of Money in Low-Wage Transnational Families, Stanford University Press, Stanford, CA.

Trung Kien 2013, 'Hỗ trợ phụ nữ lấy chồng nước ngoài tái hòa nhập cộng đồng' ['Support for Women who have Married Foreign Husbands to Reintegrate into the Community'], 12 August 2013, An Ninh Hải Phòng [Hai Phong Security], available at www.anhp. vn/phong-su/201308/ho-tro-phu-nu-lay-chong-nuoc-ngoai-taihoa-nhap-cong-dong-456058/, accessed May 2014.

Tsai, Ming-Chang 2011, "Foreign Brides" Meet Ethnic Politics in Taiwan', International Migration Review, vol. 45, no. 2, pp. 243-268. 
Tsing, Anna 2002, 'The Global Situation', in Jonathan Xavier Inda and Renato Rosaldo (eds), The Anthropology of Globalization: A Reader, Blackwell, Oxford, pp. 453-485.

Urry, John 2000, Sociology Beyond Societies: Mobilities for the TwentyFirst Century, International Library of Sociology, Routledge, London.

Urry, John 2007, Mobilities. Polity Press, Cambridge.

Uỷ Ban Biên Giới Quốc Gia 2000, 'Hiệp định hợp tác nghề cá ở Vịnh Bắc Bộ giữa Chính phủ nước Cộng hoà xã hội chủ nghĩa Việt Nam và Chính phủ nước Cộng hoà nhân dân Trung Hoa' ['Agreement on Fishery Cooperation in the Tonkin Gulf between Vietnam and China'], 18 April 2000, Bộ Ngoại Giao [Ministry of Foreign Affairs], available at biengioilanhtho.gov.vn/vie/hiepdinhhoptacnghecand-e6a9f6ac.aspx, accessed 12 November 2013.

Vertovec, Steven 2011, 'The Cultural Politics of Nation and Migration', Annual Review of Anthropology, vol. 40, pp. 241-256.

Vijayasree, C. 2000, 'Alter-Nativity, Migration, Marginality and Narration: The Case of Indian Women Writers Settled in the West', in Ralph J. Crane and Radhika Mohanram (eds), Shifting Continents/ Colliding Cultures: Diaspora Writing of the Indian Subcontinent, Brill, Amsterdam and Atlanta, pp. 123-134.

Wang, Hong-Zen 2007, 'Hidden Spaces of Resistance of the Subordinated: Case Studies from Vietnamese Female Migrant Partners in Taiwan', International Migration Review, vol. 41, no. 3, pp. 706-727.

Wang, Hong-Zen, and Shu-Ming Chang 2002, 'The Commodification of International Marriages: Cross-border Marriage Business between Taiwan and Viet Nam', International Migration, vol. 40, no. 6, pp. 93-116.

Wilding, Raelene 2007, 'Transnational Ethnographies and Anthropological Imaginings of Migrancy', Journal of Ethnic and Migration Studies, vol. 33, no. 2, pp. 331-348. 
CONNECTED \& DISCONNECTED IN VIET NAM

Winkels, Alexandra 2012, 'Migration, Social Networks and Risk: The Case of Rural to Rural Migration in Vietnam', Journal of Vietnamese Studies, vol. 7, no. 4, pp. 92-121.

Zhang, Li 2002, Strangers in the City: Reconfigurations of Space, Power, and Social Networks Within China's Floating Population, Stanford University Press, Stanford. 
This text is taken from Connected and Disconnected in Viet Nam: Remaking Social Relations in a Post-socialist Nation, edited by Philip

Taylor, published 2016 by ANU Press, The Australian National University, Canberra, Australia. 